\title{
Validity and reliability study of the attitude scale towards second foreign language learning
}

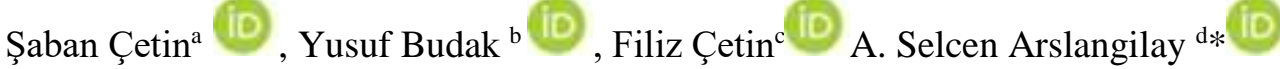 \\ ${ }^{a, b, c, d}$ Gazi University, Gazi Faculty of Education, Educational Sciences Department, Turkey
}

\section{APA Citation:}

Çetin, S., Budak, Y., Çetin, F., \& Arslangilay, A. S. (2019). Validity and reliability study of the attitude scale towards second foreign language learning.Journal of Language and Linguistic Studies, 15(3), 972-988.

Submission Date:17/06/2019

Acceptance Date:09/08/2019

\begin{abstract}
In this study it is aimed to develop a measurement tool to determine the attitudes of foreign language teacher candidates towards a second foreign language. The item pool was prepared by literature review and teacher candidates' views and finalized by taking expert opinions. The 61 item preliminary form was applied to 504 teacher candidates studying in different grades of Foreign Language Teaching Departments of Gazi University Gazi Faculty of Education in 2018-2019 academic year Spring semester. Analyses towards determining the psychometric features of the scale were made on the data set obtained from the application. The data set was applied first Exploratory Factor Analysis (EFA) for construct validity and then Confirmatory Factor Analysis (CFA). The exploratory and confirmatory analyses were made on two groups by dividing the total student number into two. EFA was conducted on the first group $\left(n_{1}=252\right)$ whereas CFA was conducted on the second group $\left(n_{2}=252\right)$. At the end of exploratory factor analysis, the scale was observed to consist of 43 items and 3 subdimensions. The sub-dimensions were named according to the judgments the scale items reflected as "positive belief towards learning a second foreign language", "resistance to learning a second foreign language" and "attaching importance to learning a second foreign language". The three factor structure about the scale explains the $49.72 \%$ of the total variance. At the end of the reliability analysis Cronbach alpha reliability coefficient for the overall scale is .95 , for sub-dimensions respectively as .95 and .90 and .76 . The model fit indices for the scale at the end of the confirmatory factor analysis are determined as RMSEA, .076; $\chi 2 / \mathrm{df}=2.4 ; \mathrm{SRMR}=.81 ; \mathrm{NFI}=.94$; $\mathrm{NNFI=.96;} \mathrm{IFI=96;} \mathrm{CFI=.96;} \mathrm{RFI=94.} \mathrm{Values} \mathrm{obtained} \mathrm{from} \mathrm{confirmatory} \mathrm{factor} \mathrm{analysis} \mathrm{are} \mathrm{in} \mathrm{acceptable}$ reference range and shows that 3 factor scale construct is validated.
\end{abstract}

(C) 2019 JLLS and the Authors - Published by JLLS.

Keywords:Learning a second foreign language; attitude; developing an attitude scale; validity; reliability.

\section{Introduction}

Human beings could achieve a multidimensional and flexible level and change their point of views the more when they enhance their knowledge and manners, explore their environment and meet with different cultures and civilizations. In this context, if one abolishes the stereotypes in his/her mind, then

\footnotetext{
${ }^{*}$ Corresponding author. Tel.: +090-312-202 1821

E-mail address: aslihanselcen@gmail.com
} 
s/he could develop wider behavior patterns and open her/himself up to the world. By this way could sustain their lives as a compatible member of their societies as well as the other communities (Risager, 2006). With no doubt all these could be actualized if both the mother languages and foreign languages are effectively learnt and taught. Because it is the language that has a prerequisite value in taking a place in social environment, awakening respect, developing a positive sense of self, exploring new cultures and countries, comprehend one's own cultural richness, observing the differences among the countries, meeting the requirements of international mobility, shortly for solving many problems (Optimum Languages, 2019; Uslu \& Özek, 2004). Therefore, learning at least one foreign language in addition to mother language learning is should be among the basic contents of the curricula. Today the importance of learning a foreign language is so apparent that there is no need for making an effort to prove it.

\subsection{Literature review}

It is inevitable that only mother language would be inadequate in having a say in international mutual initiatives in the presence of cooperation and communication necessity. Concepts and their reflections in life related to globalization, universal peace, mutual interaction, collaboration and communion in the context of ever increasing international multifaceted relations are considered universally important (Favell, Feldblum \& Smith, 2007; Kanlı̈z, 2012; Kuşçu, 2018; Öztemel \& Günday, 2013). It would not be wrong to say that those who could behave consistent with these concepts and approaches, develop an entrepreneurial spirit, stand to and manage the developments are called as contemporary individuals and information and communication age human. It is a known fact that among the basic features of modern human beings constitutes foreign language competency. Many countries provide their students flexible learning practices for learning foreign languages in order to raise individuals who could accommodate themselves to the current situation, who are conscious of their cultures as well as know the other cultures, who have a voice in international platforms, who can advocate their rights and respect to the cultures of the others.

Effective communication power in foreign languages could also provide someone to better know the other nations and live national values consciously and develop them. Communication is "the process of sharing opinion, information, attitude, emotion and skills in order to generate behavior change" (Çilenti, 1988, p. 43). Individuals or societies with foreign language competencies could gain new cognitive, affective and psychomotor behavior patterns and point of views which are richer than the ones determined by their cultures' limits as well as be the part of a wider world (Vivaling, 2019). In other words, the individual or the society who can communicate in a foreign language could go beyond the patterns of their own cultures and could prosper in world of thought and behaviors. It is the culture being lived in that determines the perception of the individual towards her/his environment and so s/he could look on the phenomenon on this assigned frame. Individuals could have the opportunity to meet the other cultures with the help of the foreign language acquired. So, the worldview and perception could change and become varied and rich (İşcan, 2011; Öztemel \& Günay, 2013). Especially the fact that those who know more than one foreign language maintains a more conscious and healthy life in many aspects is proved by a research. According to the aforementioned research results communication in foreign languages enhances creativity (Le point, 2019).

Today's world, in which the information is produced swiftly; communication, interaction and sharing is spread with instantaneous velocity and changes chase one after another effect the individual and the society and acquiring new behaviors is needed in order to keep up with the course of events. Modern societies take measures such as bringing up multilingual citizens for the sake up understanding each other correctly and in this respect they have made and still make plans as teaching more than one foreign languages in educational institutions. For instance, the European Union member countries make 
practices related with multilingualism both on the country basis and also in accordance with the Union's directive foreign language projects and decisions (Garabédian, 2013; Kuşçu, 2018).

Information, communication, technology, tourism and finance fields are among the most important sectors in economy recently. By virtue of the communication revolution, since the instant communication is provided, cultures interact with the other cultures swiftly (Bozkurt, 2000). In the globalized world, especially the immigrant receiving countries, multilingualism and multiculturalism gain importance in education and many other sectors.

It could be said that one part of universality is cultural, scientific and technologic accumulation whereas the second part the communication power that will provide the sharing of this accumulation. This is possible with teaching more than one foreign language. Nations are gradually converging one another and build close relationships. This could be said because of the desire to have a say in international societies and monitor the development closely as well as the development need that make the countries dependent to each other.

In such a context the competency to be able to communicate in one than more foreign languages come into prominence as a basic need. International and supranational institutions such as European Council support effort and projects that promote and guide teaching one than one foreign languages in the member states (Hermans, 1997). In a research it was shown that $33 \%$ of the primary school students in the European Union member states know a second language (Demirel, 2005).

At this stage it is observed that teaching more than one foreign language is perceived as a need in most countries and students are provided as much as possible with learning more than one foreign languages in the curricula (Krzyżanowski \& Wodak, 2011). It is a known fact that in order for people to understand one another fully more than one foreign language should be learnt in today's world in which multilingual and multicultural education and lifestyles manifest themselves. In other words, information and communication age requires foreign language acquisition in order to be able to communicate. It is inevitable for an individual to face with multilingual and multicultural environments at any time with any professional or any other reasons. The way to meet the social needs such as make one's presence felt, self-expression and have a voice in these kinds of environments is communication in foreign language/s. Information and communication age also requires individuals alongside with countries to build communication bridges with individual from different nations either in terms of professional or hobby or lifelong learning and integration (Çalık \& Sezgin, 2005; Gündoğdu, 2005).

In these circumstances the discussions in our country about whether second foreign language teaching should be included in our curricula and if included should it be compulsory or selective could not be said to have reached a clear result. However, today we do not seem to have been successful in the foreign language education that lasts for thousand hours starting from primary school second grade until higher education institutions (Kuşçu, 2018). Certainly it is against the grain to make education in a foreign language in an independent country. On the other hand, effective foreign language teaching has a critical role in a country's development, sustainment of their independency and strengthen it.

It is observed that learning a foreign language is an important factor of contribution in terms of personal development and autonomous learning, learning another foreign language and lifelong learning (Eren, 2018). It is especially important for teachers and teacher candidates to exchange information with the other teachers and professional associations established by teachers in terms of professional development. Both in our country as well as the others it is foreign language teacher candidates who are the closest to be able to integrate into this situation. It is a fact that competency in one foreign language has a motivating and facilitative role in learning a second foreign language as well as communication with different people. Competency in one foreign language has an important role in achieving competency in a second foreign language and it could facilitate the learning of a second foreign language 
(Eren, 2018; Le point, 2019). It could be a wise practice to provide the opportunity to learn a second foreign language to foreign language teachers and their ability to benefit from that opportunity. It is the foreign language teachers who are the bearers of language teaching in our country that is striving for integrating to the modern world. It is important for foreign language teachers to learn a second foreign language in terms of both the multilingualism conception and closing the teacher gap as teachers who knows two foreign languages could be employed as teachers with two branches. However, this is only possible if the teacher candidate has a positive attitude towards learning a second foreign language so behave as needed. Attitudes are not feelings that come into being or lose its power in an instant even brought from the birth (İnceoğlu, 2004; Üstündağ, 2001). So teacher candidate's training process is an important opportunity to raise positive attitudes towards learning a second foreign language. However, when the literature is examined it is seen that although there are various studies on attitudes towards learning a second or a foreign language, there is no study on attitudes towards learning a second foreign language. This study is believed to fulfill this gap.

\subsection{Research questions}

In this study, it was aimed to develop an attitude scale to reveal the attitudes of the abovementioned teacher candidates towards second foreign language learning.

\section{Method}

In this research survey model was used and the current situation was tried to be described as it is. Survey study is an approach that aims to describe a situation, event, individual, society or an object in past or in the current time in its own conditions and as it is. In this context this research has a descriptive feature in survey method (Balc1, 2015; Büyüköztürk, Kılıç-Çakmak, Akgün, Karadeniz \& Demirel, 2016).

\subsection{Sample / Participants}

The study population of the study consisted of 1652 teacher candidates studying in different grades in Gazi University, Gazi Faculty of Education Foreign Language Teaching in 2018-2019 academic year Spring semester. As for the difficulty of reaching the whole population, sample was taken. Systematic random sampling method was used in the research and student lists from the chosen departments were taken into account. The sample of the study was 504 teacher candidates, 372 of whom were female and 132 of whom were male and voluntarily participated in the study. Reference values in the literature on the subject were taken into account while determining the number of the teacher candidates to be included in the sample. When the related literature is examined it is seen that 100 sample is weak, 200 is intermediate, 300 is good, 500 is very good and 1000 is excellent (Comrey \& Lee, 1992; Field, 2013; Tabachnick \& Fidell, 2007). In this respect the sample of this study can be said to be in the appropriate standard value range. The total number of the students were divided into two and the analyses were made on two various groups. EFA was conducted on the first group $(n 1=252)$ whereas CFA was conducted on the second group ( $\mathrm{n} 2=252)$.

\subsection{Scale development}

During the scale development process first the related literature was investigated as well as the short compositions of the teacher candidates' opinions on the subject were looked into. The test items were created in this way. In order for evaluating the content validity of the scale items, opinions from a group 
of five language and measurement and evaluation experts were taken. In accordance with expert views 61 item preliminary form was formed.

The validity and reliability analyses of the scale were carried out on the data obtained from the application of the preliminary form on 252 teacher candidates. SPSS program was used in the analysis of the data. Whereas the exploratory analysis was done with SPSS 18.0 packet program, confirmatory factor analysis was done with Lisrel 8.50 program (Linear Structural Relation Statistics Package Program). In determining the number of the factors, generally more than one criteria are taken into account. Among these criteria is Kaiser criteria (eigenvalues $\geqslant 1$ ), Scree plot test, total variance explained and parallel analysis. The result of scree plot analysis indicated that the breaking point is in three points and the total variance explained is in an acceptable rate in (50-60\%) in social sciences (Koyuncu \& K1lı̧, 2019). Cronbach Alpha reliability coefficient and item total correlation on scale items were calculated first on the data. Items under 0.30 and with negative values on item total correlation values were excluded from the scale. In respect of construct validity of the scale KMO (Kaiser-Meyer-Olkin) and Barlett test was applied. 18 items the item load factor of which were under .45 and those taken closer values in more than one factors at the same time were excluded from the scale (De Vellis, 2003; Field, 2013). Independent samples t-test was performed in comparing high-low group $27 \%$ in determining the distinctiveness of all items in terms of attitudes towards learning a second foreign language. Finally, confirmatory factor analysis (CFA) was made using Lisrel 8.50 package program in order to determine whether the 43 item and three-dimension attitude scale's construct was validated or not.

\section{Results}

\subsection{Results related to the validity of the scale}

Exploratory and confirmatory factor analysis was applied for construct validity. Findings on the both analyses are given below:

\subsubsection{Exploratory Factor Analysis}

Kaiser-Meyer-Olkin (KMO) and Barlett Spehericity values were calculated for the appropriateness of the data set formed after the implementation for factor analysis. KMO value was calculated as .91 for the factor analysis of the structure of the 61 items in the scale. As the result of the Barlett test Barlett Spehericity value was found as $[\mathrm{X} 2=4076,546 ; \mathrm{p}<.001]$. It was observed that the values attained for factor analysis are in ideal criterion (Aiken, 2000; Field, 2003; Pallant, 2001). In order to determine the sub-factors of the scale varimax rotationmethod was used. Factor rotation methods are generally divided into two as orthogonal and oblique rotations. Oblique rotation is generally used if the factors are correlated; whereas orthogonal rotations are used when this correlation is less. The most commonly used orthogonal rotation methods are quartimax and varimax methods. Quartimax method aims to minimize the number of factors giving high loadings to more than one items, however varimax minimizes the number of items that have high loadings on more than one factor. In this research, varimax rotation was used as the correlations of the factors is in medium level (Costello \& Osborne, 2005; Tabachnick \& Fidell, 2012; Yong \& Pearce, 2013).

As 0.45 and over load values are accepted to be good enough for factor load values, this value was taken as reference value (Büyüköztürk, 2007; Seçer, 2015). As a result of varimax rotation, 3 factors the eigenvalue of which were higher than 1 were identified. The explained variance of these 3 determined values of the total variance is $49.72 \%$. This rate is considered adequate if it is between $40 \%$ and $60 \%$ in 
social sciences. Moreover, that the variance rate is high is an evidence of the strength of factor structure (Şencan, 2005; Tavşanc1l, 2014).

Scree Plot Graphic formed according to the eigenvalue of the factors in factor analysis is shown in Figure 1:

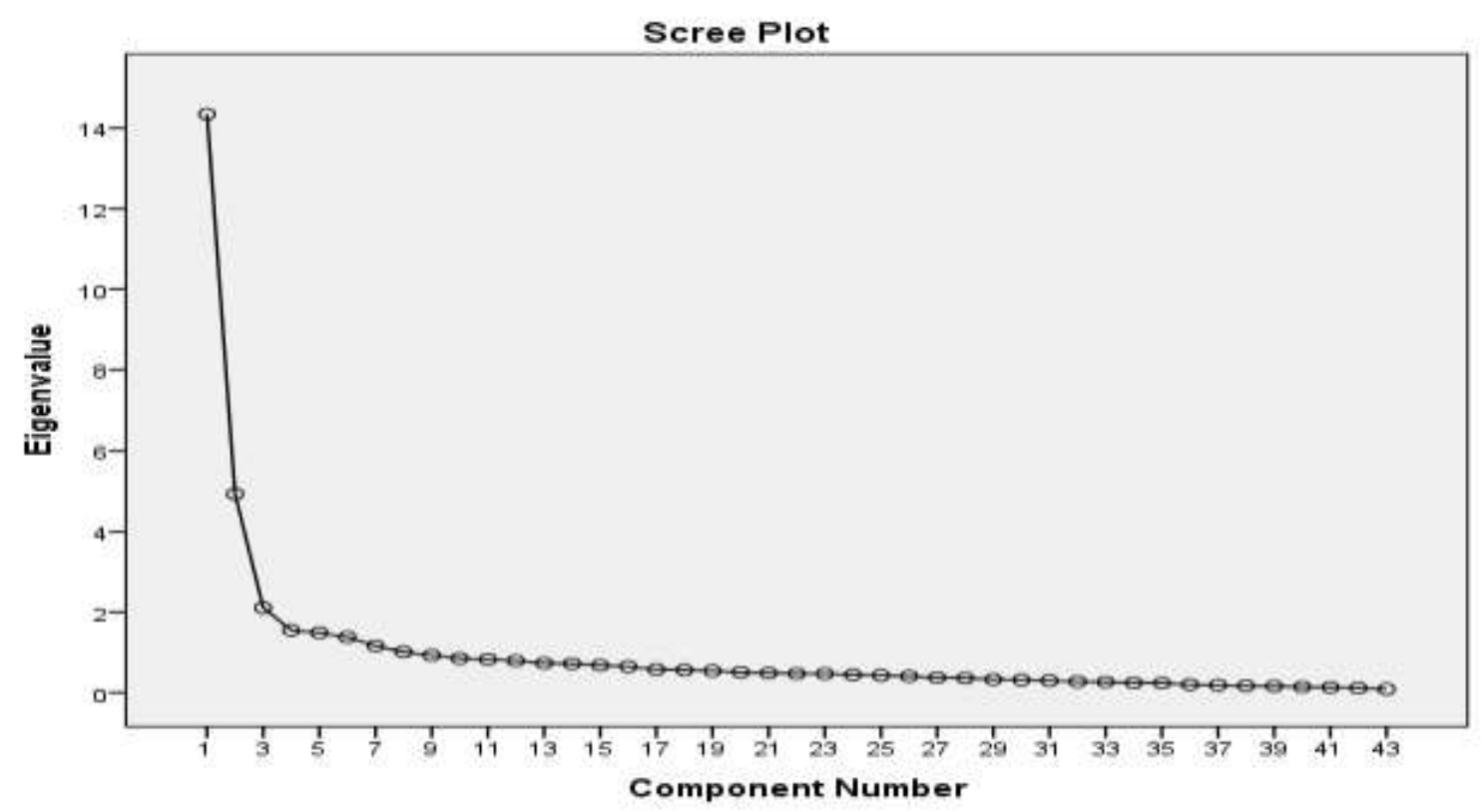

Figure 1. Scale eigenvalue factor graphic

Values with regard to Exploratory Factor Analysis (EFA) related to scale and the factors in the scale are given in Table 1: 
Table 1. Exploratory factor analysis results for the attitude scale towards learning a second foreign language

$\begin{array}{ccccc} & \text { Factor } & \text { Varimax } & \text { Factor } \\ \text { FACTORS } & \text { Common } & \text { Factor } & \text { Eigenvalue } & \text { Explained } \\ \text { Variance } \%\end{array}$

\begin{tabular}{|c|c|c|c|c|}
\hline $\begin{array}{l}\text { Factor 1:Positive belief towards learning a second } \\
\text { foreign language }\end{array}$ & & & 14.344 & 24.554 \\
\hline $\begin{array}{l}\text { 34.I create an opportunity for myself to learn a } \\
\text { second foreign language }\end{array}$ & .607 & .776 & & \\
\hline $\begin{array}{l}\text { 6.I like joining activities which guide learning a } \\
\text { second foreign language. }\end{array}$ & .622 & .771 & & \\
\hline $\begin{array}{l}\text { 21. I can devote my spare time to learn a second } \\
\text { foreign language. }\end{array}$ & .647 & .758 & & \\
\hline $\begin{array}{l}\text { 33. I use all the opportunities for learning a second } \\
\text { foreign language. }\end{array}$ & .572 & .755 & & \\
\hline $\begin{array}{l}\text { 51.Learning a second foreign language increases my } \\
\text { motivation in language learning. }\end{array}$ & .587 & .736 & & \\
\hline 5.I like learning a second foreign language. & .681 & .731 & & \\
\hline $\begin{array}{l}\text { 12.Any activity I do for learning a second foreign } \\
\text { language makes me happy. }\end{array}$ & .553 & .696 & & \\
\hline $\begin{array}{l}\text { 52. Nothing can prevent me from learning a second } \\
\text { foreign language. }\end{array}$ & .466 & .682 & & \\
\hline $\begin{array}{l}\text { 22. Having learnt a second foreign language provides } \\
\text { me to be more active in my life. }\end{array}$ & .484 & .651 & & \\
\hline $\begin{array}{l}\text { 4.The idea of learning a second foreign language } \\
\text { attracts my attention. }\end{array}$ & .621 & .642 & & \\
\hline 2. I wonder about learningdifferent languages. & .555 & .641 & & \\
\hline $\begin{array}{l}20 . \mathrm{I} \text { believe that I can learn a second foreign } \\
\text { language as good as the language I know. }\end{array}$ & .437 & .639 & & \\
\hline $\begin{array}{l}\text { 13. I attach importance to learning a second foreign } \\
\text { language. }\end{array}$ & .675 & .632 & & \\
\hline $\begin{array}{l}\text { 40.A second foreign language provides someone to } \\
\text { understand others more easily. }\end{array}$ & .496 & .632 & & \\
\hline 29.I want also to teach a second foreign language. & .478 & .627 & & \\
\hline $\begin{array}{l}\text { 28.I find learning a second foreign language } \\
\text { enjoyable. }\end{array}$ & .567 & .608 & & \\
\hline $\begin{array}{l}\text { 41.Asecond foreign language eases communication } \\
\text { with people. }\end{array}$ & .456 & .594 & & \\
\hline $\begin{array}{l}\text { 50.I enjoy reading writings, books and etc. on } \\
\text { learning a second foreign language. }\end{array}$ & .382 & .567 & & \\
\hline $\begin{array}{l}\text { 1.For me a second foreign language opens the doors } \\
\text { of a different culture. }\end{array}$ & .451 & .559 & & \\
\hline 7.I do not hesitate to learn second foreign language. & .436 & .557 & & \\
\hline $\begin{array}{l}\text { 3.I believe that a second foreign language will } \\
\text { broaden my perspective. }\end{array}$ & .387 & .519 & & \\
\hline $\begin{array}{l}\text { 17.I never have worry on learning a second foreign } \\
\text { language. }\end{array}$ & .272 & .512 & & \\
\hline $\begin{array}{l}\text { 44.I think that a second foreign language can } \\
\text { develop my creativity. }\end{array}$ & .349 & .506 & & \\
\hline $\begin{array}{l}\text { 18.It is important for someone who will be a foreign } \\
\text { language teacher to learn a second foreign language. }\end{array}$ & .337 & .503 & & \\
\hline$\frac{\text { Factor 2: }}{\text { language. }}$ Resistance to learn a second foreign & & & 4.927 & 16.036 \\
\hline $\begin{array}{l}\text { 48. I never think of learning second foreign } \\
\text { language. }\end{array}$ & .795 & .876 & & \\
\hline
\end{tabular}




\begin{tabular}{|c|c|c|c|c|}
\hline $\begin{array}{l}\text { 46.I do not think that learning second foreign } \\
\text { language will contribute to me. }\end{array}$ & .680 & .820 & & \\
\hline $\begin{array}{l}\text { 47.I do not think that learning second foreign } \\
\text { language will make a difference in me. }\end{array}$ & 682 & .815 & & \\
\hline $\begin{array}{l}\text { 49.Learning second foreign languages not an } \\
\text { engagement that will contribute to my teaching } \\
\text { profession. }\end{array}$ & .601 & .764 & & \\
\hline $\begin{array}{l}\text { 45.It is the job of idle fellowsto learn a second } \\
\text { foreign language. }\end{array}$ & .449 & .668 & & \\
\hline $\begin{array}{l}\text { 53. Learning second foreign language is the last thing } \\
\text { to come to my mind. }\end{array}$ & .454 & .665 & & \\
\hline $\begin{array}{l}\text { 38.I get annoyed of even thinking about learning } \\
\text { second foreign language. }\end{array}$ & .546 & .651 & & \\
\hline $\begin{array}{l}\text { 54. Activities on learning second foreign language } \\
\text { are boring for me. }\end{array}$ & .485 & .638 & & \\
\hline $\begin{array}{l}\text { 56.I find the academic activities on learning a second } \\
\text { foreign language useless. }\end{array}$ & .470 & .601 & & \\
\hline $\begin{array}{l}\text { 58.I do not care about what learning second foreign } \\
\text { language gains an individual. }\end{array}$ & .374 & .599 & & \\
\hline $\begin{array}{l}\text { 25. I do not think that I could learn second foreign } \\
\text { language no matter how hard I try. }\end{array}$ & .359 & .511 & & \\
\hline $\begin{array}{l}\text { 26.I never think of learning a second foreign } \\
\text { language. }\end{array}$ & .440 & .486 & & \\
\hline $\begin{array}{l}\text { 55.I think that I missed the opportunity to learn a } \\
\text { second foreign language in my childhood time. }\end{array}$ & .263 & .466 & & \\
\hline $\begin{array}{l}\text { Factor 3: Attaching importance to learning second } \\
\text { foreign language }\end{array}$ & & & 2.108 & 9.130 \\
\hline 10.I want to learn a second foreign language. & .476 & .672 & & \\
\hline $\begin{array}{l}\text { 15.Learning a second foreign language is boring for } \\
\text { me. }\end{array}$ & .520 & .645 & & \\
\hline $\begin{array}{l}\text { 9.Learning a second foreign language seems } \\
\text { meaningless to me. }\end{array}$ & .452 & .634 & & \\
\hline $\begin{array}{l}\text { 11.I do not want to learn a second foreign language } \\
\text { even if it is compulsory. }\end{array}$ & .338 & .568 & & \\
\hline $\begin{array}{l}\text { 14.I think that learning a second foreign language } \\
\text { will contribute to my personal development. }\end{array}$ & .444 & .499 & & \\
\hline $\begin{array}{l}\text { 27.The effort to learn a second foreign language } \\
\text { discomforts me. }\end{array}$ & .435 & .461 & & \\
\hline Scale Total & & & & 49.720 \\
\hline
\end{tabular}

\subsubsection{Confirmatory factor analysis}

In order for determining the model fit indices of the construct generated from the exploratory factor analysis, confirmatory factor analysis (DFA) has been performed taking into account the reference model fit indexes. At the end of the confirmatory factor analysis, model fit values related to the model are determined as RMSEA, .076; $\chi 2 / \mathrm{df}=2.4 ; \mathrm{SRMR}=.81 ; \mathrm{NFI}=.94 ; \mathrm{NNFI}=.96 ; \mathrm{IFI}=96 ; \mathrm{CFI}=.96$; $\mathrm{RFI}=94$. The model fit indices of the model were performed referencing the model fit values given in Table 2. At the end of the evaluation it was seen that current values about the scale were between acceptable reference range (Kline, 2011; Raykov \& Marcoulides, 2006; Schermelleh-Engel \& Moosbrugger, 2003; Schumacker \& Lomax, 2004; Seçer, 2015). 
Table 2. Model fit reference values

\begin{tabular}{lcccc}
\hline $\begin{array}{c}\text { Model Fit } \\
\text { Measurements }\end{array}$ & $\begin{array}{c}\text { Good Model Fit } \\
\text { Indices }\end{array}$ & $\begin{array}{c}\text { Acceptable Model Fit } \\
\text { Indices }\end{array}$ & $\begin{array}{c}\text { Model Fit Indices of } \\
\text { the Current } \\
\text { Model }\end{array}$ & Model Fit \\
\hline Chi-quare/sd & $\chi 2 / \mathrm{sd} \leq 2$ & $\chi 2 / \mathrm{sd} \leq 3$ & 2.4 & Acceptable \\
RMSEA & $0.00<\mathrm{RMSEA}<0.05$ & $0.05<\mathrm{RMSA}<0.10$ & 0.076 & Acceptable \\
SRMR & $0.00<\mathrm{SRMR}<0.05$ & $0.05<\mathrm{SRMR}<0.10$ & 0.081 & Acceptable \\
NFI & $0.95<\mathrm{NFI}<1.00$ & $0.90<\mathrm{NFI}<0.95$ & 0.94 & Acceptable \\
NNFI & $0.97<\mathrm{NNFI}<1.00$ & $0.95<\mathrm{NNFI}<0.97$ & 0.96 & Acceptable \\
IFI & $0.95<\mathrm{IFI}<1.00$ & $0.90<\mathrm{NFI}<0.95$ & 0.96 & Good model fit \\
CFI & $0.95<\mathrm{CFI}<1.00$ & $0.90<\mathrm{CFI}<0.95$ & 0.96 & Good model fit \\
RFI & $0.90<\mathrm{RFI}<1.00$ & $0.85<\mathrm{RFI}<0.90$ & 0.94 & Good model fit \\
\hline
\end{tabular}


Path diagram and factor load values resulting from confirmatory factor analysis are seen in Figure 2:

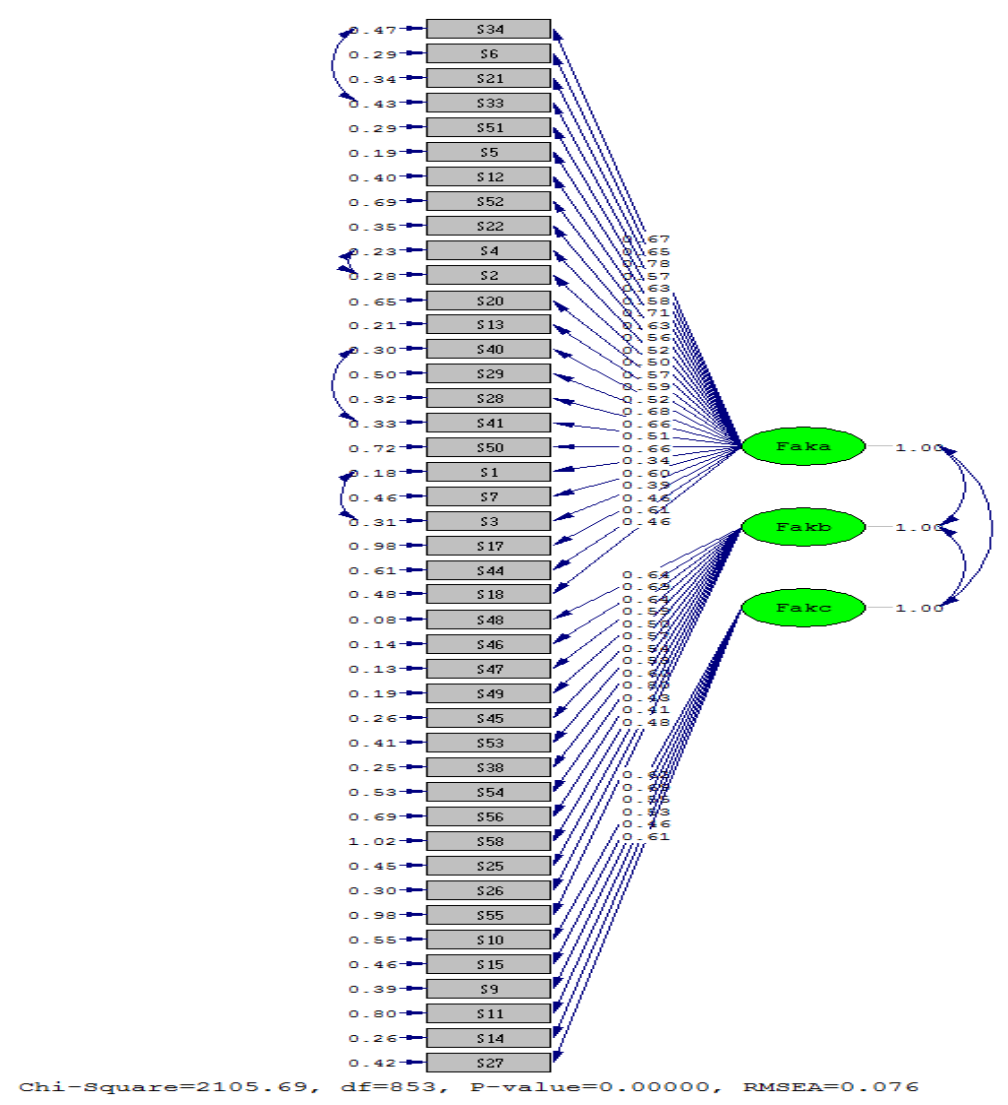

Figure 2. Path diagram on the results of the confirmatory factor analysis

\subsection{Results related to the reliability of the scale}

For the reliability of the scale, Cronbach Alpha reliability coefficients were examined for the whole scale and its sub-dimensions and item test total correlations for each scale item were calculated. In the next phase, independent samples t-test was performed in order to determine the significance of the difference between the high-low $27 \%$ groups' average scores. In addition to these analyses, internal consistency coefficient for the two equal halves of the scale and as an indicator of internal consistency, correlation coefficients among the sub-dimensions as well as the whole scale were calculated. The results of the performed reliability results are seen in Table 3 and 4 : 
Table 3. Results of the reliability analysis

\begin{tabular}{|c|c|c|c|}
\hline Factor -Item no & $\begin{array}{l}\text { Item Total } \\
\text { Correlation }\end{array}$ & $\begin{array}{c}\text { High-Low } 27 \% \\
\mathrm{t}\end{array}$ & $\begin{array}{c}\text { Cronbach Alfa } \\
\text { Internal Consistency } \\
\text { Coefficient }\end{array}$ \\
\hline Factor I & & & .95 \\
\hline Item34 & .611 & $13.816^{* * *}$ & \\
\hline Item6 & .647 & $14.538 * * *$ & \\
\hline Item 21 & .721 & $16.178 * * *$ & \\
\hline Item33 & .570 & $12.248 * * *$ & \\
\hline Item51 & .668 & $12.330^{* * *}$ & \\
\hline Item5 & .674 & $13.271 * * *$ & \\
\hline Item12 & .663 & $16.369 * * *$ & \\
\hline Item52 & .507 & $10.788 * * *$ & \\
\hline Item 22 & .613 & $12.520 * * *$ & \\
\hline Item4 & .635 & $11.167 * * *$ & \\
\hline Item2 & .596 & $9.720 * * *$ & \\
\hline Item 20 & .504 & $10.647 * * *$ & \\
\hline Item 13 & .760 & $14.453 * * *$ & \\
\hline Item40 & .643 & $10.614 * * *$ & \\
\hline Item29 & .631 & $11.796^{* * *}$ & \\
\hline Item 28 & .717 & $12.035^{* * *}$ & \\
\hline Item41 & .616 & $10.525^{* * *}$ & \\
\hline Item50 & .540 & $9.277 * * *$ & \\
\hline Item1 & .563 & $9.091 * * *$ & \\
\hline Item 7 & .543 & $10.849 * * *$ & \\
\hline Item3 & .485 & $8.698 * * *$ & \\
\hline Item17 & .341 & $7.617 * * *$ & \\
\hline Item44 & .543 & $9.583 * * *$ & \\
\hline Item18 & .527 & $9.287 * * *$ & \\
\hline Factor II & & & .90 \\
\hline Item48 & .560 & $6.698 * * *$ & \\
\hline Item46 & .454 & $5.213 * * *$ & \\
\hline
\end{tabular}




\begin{tabular}{|c|c|c|c|}
\hline Item47 & .482 & $6.900 * *$ & \\
\hline Item49 & .467 & $6.998 * * *$ & \\
\hline Item45 & .364 & $4.659 * * *$ & \\
\hline Item53 & .384 & $6.032 * * *$ & \\
\hline Item38 & .506 & $6.159 * * *$ & \\
\hline Item54 & .536 & $9.458 * * *$ & \\
\hline Item56 & .569 & $10.036^{* * *}$ & \\
\hline Item58 & .385 & $8.240 * * *$ & \\
\hline Item 25 & .505 & $8.375 * * *$ & \\
\hline Item26 & .542 & $7.668 * * *$ & \\
\hline Item55 & .531 & $6.177 * * *$ & \\
\hline Factor III & & & .76 \\
\hline Item10 & .371 & $6.319 * * *$ & \\
\hline Item15 & .504 & $7.745 * * *$ & \\
\hline Item9 & .421 & $6.791 * * *$ & \\
\hline Item11 & .324 & $4.942 * * *$ & \\
\hline Item14 & .558 & $13.381 * * *$ & \\
\hline Item27 & .500 & $8.448 * * *$ & \\
\hline Scale Total & & & .95 \\
\hline
\end{tabular}

When the reliability analysis results on the scale in Table 3 are examined, it is seen that the Cronbach Alpha reliability coefficients are starting from the first sub-dimension as .95 and .90 and .76. This value is 0.95 for the overall scale. Item total correlation coefficients detected for the items in the scale vary between 0.32-0.76. T-test results performed between the scores of high-low 27\% groups for all the items in the scale differ in $\mathrm{P}<.001$ significance level. Spearman-Brown internal consistency coefficient which is shown as an evidence that all items in the scale measure the same feature and calculated for equal halves of this scale was detected as having a high value as " 0.86 ". On the other hand, there are findings on the correlation values which are indicated as internal consistency indicators between the overall scale and the sub-dimensions in Table 4: 
Table 4. Correlation values between the scale in general and the sub-dimensions

\begin{tabular}{llll}
\hline & Scale Total & Factor I & Factor II \\
\hline I.Sub-Dimension & $.916^{* *}$ & -------- & \\
II. Sub-Dimension & $.734^{* *}$ & $.433^{* *}$ &.------ \\
III. Sub-Dimension & $.681^{* *}$ & $.503^{* *}$ & $.465^{* *}$ \\
\hline$*$ P $<.01$ & & &
\end{tabular}

It is observed that the correlation values in Table 4 reflect medium and high level positive relation in $\alpha=0.01$ significance level and 0.47 and 0.92 for the overall scale and sub-dimensions. When the reliability and validity analyses of the scale are examined, it is seen that there are a total of 43 items in the test 17 of which are negative and 26 of which are positive. The highest score that could be taken from this attitude scale with a Likert type scale is 215 whereas the lowest score is 43 .

\section{Discussion and Suggestions}

In this study it was aimed to develop a scale that would determine the attitudes of teacher candidates towards learning a second foreign language. The 61 item preliminary scale form prepared in the subject context was organized accompanied with five field experts. The scale was applied to 504 teacher candidates studying in Gazi University Gazi Faculty of Education Foreign Language Teaching Departments in 2018-2019 Spring Academic Year. The validity of the scale was tested with exploratory and confirmatory factor analysis. For the reliability of the scale, Cronbach Alpha reliability coefficient was calculated for the scale total and the sub-dimensions. As a result of the exploratory factor analysis, 18 items were eliminated from the scale. The 43 items left in the final scale consisted three dimensions as; "positive belief to learn a second foreign language", "resistance to learn a second foreign language" and "caring to learn a second foreign language". It was observed that the three factors in the scale explained $49.72 \%$ of the total variance. The Cronbach alpha reliability coefficient of the scale was for the sub-dimensions respectively as $.95, .90$ and .76 . This value is .95 for the total scale. Confirmatory factor analysis was made taking into account the reference model fit values for determining the appropriateness of the structure obtained from the exploratory factor analysis. Model fit values obtained from the confirmatory factor analysis are; RMSEA, .076; $\chi 2 / \mathrm{df}=2.4 ; \mathrm{SRMR}=.81 ; \mathrm{NFI}=.94 ; \mathrm{NNFI}=.96$; $\mathrm{IFI}=96 ; \mathrm{CFI}=.96 ; \mathrm{RFI}=94$.

When foreign literature on this subject is examined it is seen that there are studies on determining attitudes towards learning a second foreign language (Gardner \& Lambert,1972;Garrett, 2010; Hidalgo, 1984; Huguet, Lapresta, \&Madariaga, 2008; Masgoret\&Gardner, 2003) however there is very limited study in Turkey (Uslu\&Özek, 2004).

Attitudes are accepted as one of the most important psychological features that effect the perceptions, thought, choices, emotions and behaviors of an individual towards an object. Therefore, behaviors the individual could exhibit could be estimated by evaluating the attitudes (Karasar, 2009; Vogel \& Wanke, 2016). It is important in terms of estimating teacher candidates' future learning and teaching behaviors by determining their attitudes towards learning a second foreign language. The qualified estimations in this direction could be possible with the usage of measurement tools having psychometric features. It is believed that this measurement tool aimed to determine the attitudes of teacher candidates towards learning a second foreign language will both contribute to the studies to be done in this field and enrich the measurement tool literature. 


\section{References}

Aiken, L. R. (2000). Psychological testing and assessment(10 ${ }^{\text {th }}$ ed.). Boston: Allyn \& Bacon.

Balc1, A. (2015). Sosyal bilimlerde araştırma: Yöntem, teknik ve ilkeler. Ankara: PegemA Yayınevi.

Büyüköztürk, Ş. (2007). Sosyal bilimler için veri analizi el kitabı. Ankara: Pegem Akademi Yayıncılık.

Büyüköztürk, Ş., Kılıç-Çakmak, E., Akgün, Ö. E., Karadeniz, Ş., \& Demirel, F. (2016). Bilimsel araştırma yöntemleri. Ankara: Pegem.

Çalık, T. \& Sezgin, F. (2005). Küreselleşme, bilgi toplumu ve eğitim. Kastamonu Eğitim Fakültesi Dergisi, 13(1).

Comrey, A. L. \& Lee, H. B. (1992). A first course in factor analysis. Hillsdale, NJ: Erlbaum.

Costello, A. B. \& Osborne, J. W. (2005). Best practices in exploratory factor analysis: Four recommendations for getting the most from your analysis. Practical assessment, research and evaluation, 10(7), 1-9.

Çelebi, S. (2009). Teachers and students' views on anxiety in English classrooms and attitudes towards English. Unpublished Master Thesis, Çukurova University, Institute of Social Sciences, Adana.

Çilenti, K. (1988). Eğitim teknolojisi ve öğretim. Ankara: Kadığlu Matbaası.

Çimen, S. (2011). Eğitim fakültesi ögrencilerinin İngilizceye yönelik tutum, Ingilizce kaygısı ve öz yeterlik düzeylerinin incelenmesi. Unpublished Master Thesis, Zonguldak Karaelmas Üniversitesi, Institute of Social Sciences, Zonguldak.

Garrett, P. (2010). Attitudes to language. New York: Cambridge University Press.

Gündoğdu, M. T. (2005). Avrupa Birliği yolunda Türkiye'nin yabancı dil politikası. Çukurova Üniversitesi Eğitim Fakültesi Dergisi, 2(29).

Demirel, Ö. (2005). Avrupa Konseyi dil projesi ve Türkiye uygulaması. Milli Eğitim Dergisi, 33(167). Retrieved from http://dhgm.meb.gov. tr/yayimlar/dergiler/Milli_Egitim_Dergisi/167/index3demirel.htm on May 2019.

De Vellis, R. F. (2003) Scale development. California: Sage Publication Inc.

Eren, B. (2018). İkinci yabancs dil olarak Almanca eğitiminde öğrenme stillerinin belirlenmesi.Unpublished Master Thesis, Trakya University, Institute of Social Sciences, Edirne.

European Commission. (2016). Lingua - Socrates Action 4 - Language Learning and Teaching. Retrieved from http://eacea.ec.europa.eu/static/en/overview/lingua_overview.htm on May 2019.

Favell, A.; Feldblum, M., \& Smith, M. P. (2007).The human face of global mobility: A research agenda. Society, 44(2). Doi: https://doi.org/10.1007/BF02819922

Field, A. (2013). Discovering statistics using IBM SPSS statistics ( $4^{\text {th }}$ edition). London: Sage.

Garabédian, M. (1996). «Apprendre une langue quand on en parle déjà une», Revueinter nationale d'éducation de Sèvres. Retrieved from: http://journals.openedition.org/ries on May 2019.

Gardner, R.,\& Lambert, W. (1972). Attitudes and motivation in second language learning. Rowley, MA: Newbury House.

Hermans, S. (1997) World Promoting foreign language competence in the European Community: The LINGUA programme. Englishes, 16(1).

Huguet, A., Lapresta, C., \& Madariaga, J. M. (2008). A study on language attitudes towards regional and foreign languages by school children in Aragon, Spain. International Journal of Multilingualism, 5(4), 275-293. 
İnceoğlu, M. (2004). Tutum, algl, iletişim. Ankara: Kesit Tanıtım Ltd. Şti.

İşcan, A. (2011). Türkçenin yabancı dil olarak önemi. Uluslararası Avrasya Sosyal Bilimler Dergisi, 2(4).

Kanlı̈̈z, Y. (2012). eTwinning projeleri ile yaratıcı yazma çalışmaları. In: Türkçe öğretiminde güncel çalışmalar (Eds.: Aksan, M. \& Aksan, Y.) Ankara: Şafak Press.

Karasar, N. (2009). Bilimsel araştırma yöntemi: Kavramlar, ilkeler, teknikler. Ankara: Nobel Yayınc1lik.

Kline, R. B. (2011). Principles and practice of structural equation modeling (3rd ed.). New York London: The Guilford Press.

Koyuncu, İ. \& Kılıç, A.F.(2019). Açımlayıcı ve doğrulayıcı faktör analizlerinin kullanımı: Bir doküman incelemesi. Ĕgitim ve Bilim, 44(198),361-388.

Krzyżanowski, M. \& Wodak, R. (2011). Political strategies and language policies: The European Union Lisbon strategy and its implications for the EU's language and multilingualism policy. Language Policy, 10(2).

Kuşçu, E. (2018) Üniversite öğrencilerinin ikinci yabancı dil olarak Fransızca öğrenme profilleri: Pamukkale Üniversitesi Eğitim Fakültesi ve Fen-Edebiyat Fakültesi örneği. Kastamonu Eğitim Dergisi, 26(1).

Le point (2019). Pourquoi il est très important d'apprendre des langues étrangères. Retrived from: https://www.lepoint.fr/societe/pourquoi-il-est-tres-important-d-apprendre-des-langues- on May 2019.

Masgoret, A.-M., \& Gardner, R. C. (2003). Attitudes, motivation, and second language learning: A meta-analysis of studies conducted b y Gardner and associates. Language Learning, 53(1), 123163.

Optimum Langues. (2013). L'importance des langues étrangères Retrived from: https://www.optimumlangues.com/limportance-des-langues-etrangeres/ on May 2019.

Öztemel, K. \& Günday, R. (2013). İletişimsel ve eylem odaklı yönteme göre hazırlanmış ders kitaplarındaki kelime öğretimi farklılıkları. Turkish Studies-International Periodical For The Languages, Literature and History of Turkish or Turkic, 8.

Pallant, J. (2001). SPSS survival manual. Maidenheat, PA: Open University Press.

Raykov, T., \& Marcoulides, G. A. (2006). On multilevel model reliability estimation from the perspective of structural equation modeling. Structural Equation Modeling, 13, 130-141.

Risager, K. (2006). Language and culture: Global flows and local complexity. Clevedon, Multilingual Matters: Toronto

Schermelleh-Engel, K., \& Moosbrugger, H. (2003). Evaluating the fit of structural equation models: Tests of significance and descriptive goodness- of-fit measures. Methods of Psychological Research Online, 8(2), 23-74.

Schumacker, R. E. \& Lomax, R. G. (2004). A beginner's guide to structural equation modeling. London: Psychology Press.

Seçer, İ. (2015). SPSS ve LISREL ile pratik veri analizi. Ankara: Anı Yayıncılık.

Şencan, H. (2005). Sosyal ve davranışsal ölçümlerde güvenirlik ve geçerlilik. Ankara: Seçkin Yayınc1lik.

Tabachnick, B. G. \& Fidell, L. S. (2012) Using multivariate statistics. (6th Edition). Boston: Pearson Education. 
Tabachnick, B. G., \& Fidell, L. S. (2007). Using multivariate statistics. Boston: Allyn and Bacon.

Tavşancıl, E. (2014). Tutumların ölçülmesi ve SPSS ile veri analizi. Ankara: Nobel Yayıncılık.

Uslu, Z. \& Özek, Y. (2004). Yabancı dil öğretmeni adaylarının ikinci yabancı dili öğrenmeye ilişkin tutum ve görüşleri. Hasan Ali Yücel Eğitim Fakültesi Dergisi, 2.

Üstündă̆, N. (2001). Müfredat laboratuar okullarında görev yapan yönetici ve ögrretmenlerin bilgisayar tutumları ile kaygı düzeyleri arasındaki ilişkinin incelenmesi.Unpublished Master Thesis, Marmara University, Institute of Educational Sciences, İstanbul.

Vivaling. (2017).10 bonnes raisons d'apprendre une langue étrangère. Retrieved from: https://vivaling.com/10-bonnes-raisons-dapprendre-une-langue-etrangere on May 2019.

Vogel, T., \& Wanke, M. (2016). Attitudes and attitude change. NY: Routledge.

Yong, A. G. \& Pearce, P. (2013). A beginner's guide to factor analysis: Focusing on exploratory factor analysis. Tutorials in quantitative methods for Psychology, 9(2), 79-94.

\section{İkinci bir yabancı dil öğrenmeye yönelik tutum ölçeği geçerlik ve güvenirlik çalışması}

Öz

Bu çalışmada yabancı dil öğretmen adaylarının ikinci bir yabancı dil öğrenmeye yönelik tutumlarını belirlemede kullanılacak bir ölçme aracı geliştirilmesi hedeflenmiştir. Konuya ilişkin tutumları yansıtan madde havuzu gerek literatürden gerekse öğretmen adaylarının görüşlerinden yararlanılarak oluşturulmuştur. Uzman görüşlerine sunularak kesinleştirilen 61 maddelik deneme formu, Gazi Üniversitesi Gazi Eğitim Fakültesi yabancı diller öğretmenlik programlarında 2018-2019 eğitim öğretim yılı bahar döneminde farklı sınıf kademelerinde öğrenim gören 504 öğretmen adayına uygulanmıştır. Çalışma gurubuna yapılan uygulamadan elde edilen veri seti üzerinde öncelikle yapı geçerliği için Açımlayıcı Faktör Analizi (AFA), sonrasında Doğrulayıcı Faktör Analizi (DFA) yapılmıştır. Araştırmada açımlayıcı ve doğrulayıcı faktör analizi için toplam öğrenci sayısı ikiye bölünerek iki ayrı grup üzerinden yapılmıştır. Birinci grup $\left(\mathrm{n}_{1}=252\right)$ üzerinde AFA, ikinci grup $\left(\mathrm{n}_{2}=252\right)$ üzerinde DFA yapılmıştır. Açımlayıcı Faktör Analizi (AFA) sonucunda ölçeğin 43 madde ve 3 alt boyuttan oluştuğu gözlenmiştir. Ölçek maddelerinin yansıttığı yargılara dayalı olarak ölçek alt boyutları sırasıyla " İkinci bir dil öğrenmeye yönelik olumlu inanç ", " İkinci bir dil öğrenmeye yönelik direnç " ve " İkinci bir dil öğrenmeyi önemseme " şeklinde adlandırılmıştır. Ölçekle ilgili üç faktörlü yapı toplam varyansın \%49.72'sini açıklamaktadır. Güvenirlik analizi sonucunda ölçeğin geneli için Cronbach alfa güvenirlik katsayısı .95, alt boyutlar için sırasıyla .95 ile .90 ve .76 'dır. Doğrulayıcı faktör analizi sonucunda modele ilişkin uyum değerleri; RMSEA, .076; $\chi 2 / \mathrm{df}=2.4$; SRMR $=.81$; $\mathrm{NFI}=.94 ; \mathrm{NNFI}=.96 ; \mathrm{IFI}=96 ; \mathrm{CFI}=.96 ; \mathrm{RFI}=94$ tespit edilmiştir. Doğrulayıcı faktör analizi sonucunda elde edilen değerler, kabul edilebilir referans aralığında olup, 3 faktörlü ölçek yapısının doğrulandığını göstermektedir.

Anahtar sözcükler: İkinci bir yabancı dil öğrenme; tutum; tutum ölçeği geliştirme, geçerlik, güvenirlik. 


\section{AUTHOR BIODATA}

Assoc. Prof. Dr. Şaban Çetin, Gazi University, Gazi Faculty of Education, Educational Sciences Department, Curriculum and Instruction. ORCID ID: 0000-0002-4319-5667

Prof. Dr. Yusuf Budak, Gazi University, Gazi Faculty of Education, Educational Sciences Department, Curriculum and Instruction. ORCID ID: 0000-0001-9625-204X

Assoc. Prof. Dr. Filiz Çetin, Gazi University, Gazi Faculty of Education, Educational Sciences Department, Curriculum and Instruction. ORCID ID: 0000-0002-6806-0160

Dr. A. Selcen Arslangilay, Gazi University, Gazi Faculty of Education, Educational Sciences Department, Curriculum and Instruction. ORCID ID: 0000-0002-6262-9037 